\title{
Differential Responses of Soil Bacterial and Fungal Community to Short-Term Crop Tree Management in a Larix gmelinii Plantation
}

\author{
$\mathrm{Li} \mathrm{Ji}^{1}{ }^{1}$, Jiangbo $\mathrm{Yu}^{1,2}$, Xingzhe Zhang ${ }^{3}$, Yue Liu ${ }^{1}$ and Lixue Yang ${ }^{1, *}$ \\ 1 Key Laboratory of Sustainable Forest Ecosystem Management-Ministry of Education, School of Forestry, \\ Northeast Forestry University, Harbin 150040, China; jlnefu917@gmail.com (L.J.); \\ 17835422369@nefu.edu.cn (J.Y.); ly6789838@nefu.edu.cn (Y.L.) \\ 2 Institute of Eco-Landscape Planning and Design of China Forest International, Beijing 100013, China \\ 3 Chongqing Forestry Investment and Development Co., Ltd., Chongqing 401121, China; \\ xingzhe666@gmail.com \\ * Correspondence: ylx_0813@163.com; Tel.: +86-0451-82191122
}

Citation: Ji, L.; Yu, J.; Zhang, X.; Liu, Y.; Yang, L. Differential Responses of Soil Bacterial and Fungal Community to Short-Term Crop Tree Management in a Larix gmelinii Plantation. Forests 2021, 12, 1411. https://doi.org/ 10.3390/f12101411

Academic Editor: Fred O. Asiegbu

Received: 16 August 2021

Accepted: 12 October 2021

Published: 15 October 2021

Publisher's Note: MDPI stays neutral with regard to jurisdictional claims in published maps and institutional affiliations.

Copyright: (c) 2021 by the authors. Licensee MDPI, Basel, Switzerland. This article is an open access article distributed under the terms and conditions of the Creative Commons Attribution (CC BY) license (https:// creativecommons.org/licenses/by/ $4.0 /)$.

\begin{abstract}
Crop tree management (CTM) is a widely applicable silviculture technology that is used to improve the performance of individual trees. However, only little information is available about the effects of the CTM regime on the soil microbial community structure. We conducted a study to explore the effects of short-term (five years) CTM on the soil bacterial and fungal diversity, community composition, and structure in the $0-10 \mathrm{~cm}$ soil layer in a Larix gmelinii (Rupr.) Kuzen. plantation. We set out to investigate the differential response of bacterial and fungal communities to variations in soil properties mediated by short-term CTM. Compared with the control plots, the soil microbial biomass carbon and microbial biomass nitrogen in CTM increased significantly by $64.2 \%$ and $32.3 \%$, respectively. CTM significantly promoted the content of soil organic carbon, dissolved organic carbon, and nitrate nitrogen, and reduced the content of dissolved organic nitrogen. CTM changed the Shannon and Simpson indices of soil fungi to a remarkable extent but had little effect on the $\alpha$ diversity of bacterial communities. The bacterial $\beta$ diversity was more sensitive to CTM than fungi. The relative abundance of Verrucomicrobiae (the dominant class of soil bacteria) in CTM was significantly increased by $78.2 \%$, while the relative abundance of Agaricomycetes (dominant class for soil fungi) was reduced by $43.3 \%$. We observed a significantly increased number of unique OTUs for soil fungi in the CTM plots. Redundancy analysis showed that dissolved organic carbon, soil moisture, and total phosphorus content significantly affected the composition of bacterial communities, while soil dissolved organic nitrogen, $\mathrm{C} / \mathrm{N}$, and total phosphorus drove the high variation in fungal community composition. Overall, our results emphasize the divergent response of soil bacterial and fungal communities in Larix gmelinii plantations to short-term CTM. We must pay more attention to the functional role of soil microbiota in future forest management.
\end{abstract}

Keywords: crop tree management; soil bacteria; soil fungi; Larix gmelinii; forest plantation

\section{Introduction}

The principle of forest sustainability is the most important principle in forest management, requiring forest managers to develop the forest in a direction close to nature $[1,2]$. Forest thinning is one of the important and widely used silviculture methods, as it can ensure the survival rate and increase the growth rate and stand volume of trees [3]. Crop tree management (CTM), based on an individual tree, is a special approach to forest thinning that improves the quality of the individual tree by eliminating the interference of tree competition and increasing the space for crop tree growth [4,5]. It also is considered to be a critical approach in achieving close-to-nature forest management [6,7]. However, previous research has established that crop tree management has an impact on tree growth [8-11], species diversity [12-14], and fine root dynamics [15]. Currently, few studies have investi- 
gated the response of the soil microbiota and their community structure [16], limiting our understanding of the impact of CTM on soil ecosystem functions.

Soil bacteria and fungi, as important components of the soil biological community, actively participate in the decomposition of soil organic matter, the formation of humus, and the transition and cycle of soil nutrients, and play a key role in maintaining the structure and function of the ecosystem [17-19]. Their sensitivity to environmental changes is considered an important factor for predicting soil quality [20,21]. Many published studies describe the effect of forest management (especially thinning) on the soil microbial community structure and microbial biomass [22-26]. Bastida et al. [27] investigated a Maritime pine-Holm oak mixed forest in the Mediterranean and found that thinning improved the contents of soil carbon, nitrogen, and microbial biomass, and significantly altered the bacterial and fungal community compositions. In a recent meta-analysis of 377 observations around the world, Zhou et al. [26] indicated that thinning could change the soil microbial community rather than the total microbial biomass. On the one hand, forest management can provide more organic matter derived from the understory and enhance the availability of light and water [28]. On the other hand, the removal of organic matter during the forest management process reduces the nutrients returned to forest soils and further aggravates soil weathering driven by organisms $[29,30]$. To date, debate continues regarding the effect of forest management on the soil microbial community. Some reported that forest thinning increased [28] or decreased [31] the relative abundance of soil microbes; it was even suggested that the effects of forest management on microbial communities can be offset by synergistic changes in environmental factors [22].

Generally, since fungi can produce various lignocellulose enzymes, they are more capable of decomposing recalcitrant organic matter than bacteria [32]. Recently, Zhou et al. [33] found that the soil fungi are more sensitive to forest thinning than soil bacteria. Kohout et al. [34] stated that the exogenous input of carbohydrates and plant metabolites dependent on fungi are produced through forest management activities, which ultimately affect the composition of soil fungal communities. Regarding crop tree management, as a special method of forest thinning, no research has yet investigated the response of soil bacterial and fungal communities to this management approach. Yin et al. [16] revealed that crop tree releases dramatically increased the relative abundance of bacterivores and fungivores. Therefore, exploring the differential response of soil bacterial and fungal communities to CTM will contribute to a deeper understanding of the soil ecological process under forest management.

Larix gmelinii, as the dominant tree species and community-building tree species in the Greater Khingan Mountains in China, plays a vital role in maintaining the stability of the ecosystem, protecting species diversity, and promoting the sustainable development of forests. In recent years, Larix gmelinii has attracted more attention due to its plantation area, reaching more than 3 million hectares, accounting for more than $30 \%$ of the Chinese plantation area $[35,36]$. To resolve the ecological problems of low productivity, soil degradation, and loss of species diversity in larch monoculture plantations, we drew on the crop tree management regime from Germany and applied a close-to-nature management approach aimed at cultivating large-diameter larch timber. In this study, based on advanced high-throughput technology, we focused on the effect of short-term crop tree management practices on soil bacterial and fungal diversity, community composition, and structure in a Larix gmelinii plantation. We hypothesized that (1) short-term crop tree management practices will improve the soil bacterial and fungal relative abundance, as well as diversity; (2) given the different life strategies of bacteria and fungi, and with fungi being closely associated with the diversity of plants and the decomposition of cellulose and lignin in plant residues [37,38], the soil fungal community structure will be more susceptive to crop tree management than soil bacteria; (3) the influence of crop tree management on the soil microenvironment will mediate the variation in both microbial communities. 


\section{Materials and Methods}

\subsection{Study Area}

The study area is located at the Lvshui Forest Farm in Songling Forest Bureau, Greater Khingan Mountains $\left(123^{\circ} 29^{\prime} 13^{\prime \prime}-125^{\circ} 11^{\prime} 10^{\prime \prime}\right.$ E, $\left.50^{\circ} 09^{\prime} 16^{\prime \prime}-51^{\circ} 23^{\prime} 48^{\prime \prime} \mathrm{N}\right)$, at an altitude of $400-700 \mathrm{~m}$. This region is characterized by a cold, temperate, continental monsoon climate with a frost-free period of 130-220 days. The annual average temperature and precipitation are $-3{ }^{\circ} \mathrm{C}$ and $600 \mathrm{~mm}$, respectively. The zonal soil is brown coniferous forest soil, interspersed with meadow soil and marsh soil. The soil type is Umbri-Gelic Cambosols. The species composition in this area is dominated by Dahurian larch (Larix gmelinii), Scots pine (Pinus sylvestris var. mongolica Litv.), white birch (Betula platyphylla Sukaczev), and aspen (Populus davidiana Dode). The understory vegetation includes Dahurian rhododendron (Rhododendron dauricum L.), ledum (Ledum palustre L.), lingonberry (Vaccinium vitis-idaea L.), saussurea (Saussurea japonica (Thunb.) DC.), and blueberry (Vaccinium uliginosum L.).

\subsection{Crop Tree Release Regime}

In the spring of 1988, Larix gmelinii plantations were afforested on a flat and uniform burned area with an initial stand density of 2400 stems.ha ${ }^{-1}$. Mechanical thinning with $31 \%$ intensity was conducted for the first time in 2013 and maintained at 1700 stems.ha $^{-1}$. The crop tree treatment was conducted in 2014. The treatments were as follows:

CK: Unthinned.CTM: In total, 150 stems of larch trees per hectare were selected as crop trees (vigorously growing with a well-developed crown, free from mechanical injuries and pests, and located in the main forest layer) $[5,16]$. The interfering and competing woody plants that affected the crop tree growth within 25 times of the diameter at the breast height of the crop tree were cut down from the sample plot (14.1\% intensity)

The thinning was conducted in winter, and the remaining felling was removed from the forest stand (i.e., stems and branches), but there was no other disturbance (such as understory management, fertilization, or irrigation, etc.). The seedlings of Pinus sibirica, Pinus sylvestris, Betula platyphylla, and Quercus mongolica Fisch. ex Ledeb. in natural regeneration were protected among forest gaps; meanwhile, based on the principle of adapting the tree to the site, the complementary planting of Fraxinus mandshurica Rupr., Juglans mandshurica Maxim., etc., by the cluster method was conducted in the understory to improve the biodiversity and create a better growth environment for crop trees. In 2019, the basic information of the CTM and CK plots was obtained by survey (Table 1).

Table 1. Basic information of L. gmelinii plantation after five years of crop trees management.

\begin{tabular}{|c|c|c|}
\hline Attribute & СТM & CK \\
\hline Stem number (trees $\cdot \mathrm{ha}^{-1}$ ) & 1311 & 1892 \\
\hline Basal area $\left(\mathrm{m}^{2} \cdot \mathrm{ha}^{-1}\right)$ & 26.62 & 34.11 \\
\hline Volume $\left(\mathrm{m}^{3} \cdot \mathrm{ha}^{-1}\right)$ & 182.09 & 230.23 \\
\hline Stand density of crop trees (trees $\cdot \mathrm{ha}^{-1}$ ) & 150 & - \\
\hline DBH for trees $(\mathrm{cm})$ & 18.59 & - \\
\hline Litter accumulation $\left(\mathrm{t} \cdot \mathrm{ha}^{-1}\right)$ & 22.37 & 23.68 \\
\hline Simpson diversity of vegetation & 0.90 & 0.79 \\
\hline Shannon diversity of vegetation & 2.57 & 2.34 \\
\hline Vegetation composition & $\begin{array}{c}\text { Larix gmelinii, Carex Pilosa Scop., } \\
\text { Equisetum arvense L., Athyrium } \\
\text { multidentatum (Kom.) Kom., Vicia sepium } \\
\text { L., Pyrola calliantha Andres, Thalictrum } \\
\text { aquilegiifolium L. }\end{array}$ & $\begin{array}{c}\text { Larix gmelinii, Carex Pilosa, Equisetum } \\
\text { arvense, Pyrola calliantha Andres, } \\
\text { Thalictrum aquilegifolium, Adenocaulon } \\
\text { himalaicum Edgew. }\end{array}$ \\
\hline
\end{tabular}




\subsection{Experimental Design and Sampling}

In July 2019, after five years of CTM, three plots $(30 \times 30 \mathrm{~m})$ were randomly selected for crop tree management (CTM) and control (CK) in this area. The location and site conditions were almost homogeneous. Each plot was surrounded by buffer zones $(10 \mathrm{~m})$ to reduce potential edge effects. These plots were $100 \mathrm{~m}$ apart from others. Eight trees (including crop trees and noncrop trees) were randomly selected in each plot (CK and CTM plots), and the soil sampling points were chosen approximately 1-2 $\mathrm{m}$ away from these tree trunks. Soil cores were collected at the $0-10 \mathrm{~cm}$ depth with a $10 \mathrm{~cm}$ diameter auger after removing the surface litter. Then, these eight samples from each plot (three replicated plots) were mixed to form one composite soil sample. These soil samples were sieved with a $2 \mathrm{~mm}$ mesh to remove roots and gravel and immediately transported in an ice cooler to the laboratory. One set of subsamples was stored at $-80^{\circ} \mathrm{C}$ for later DNA extraction, the others were used to assess the soil properties.

\subsection{Soil Properties Analysis}

The soil bulk density (BD) was measured using the cutting ring method. The soil moisture content was measured by oven-drying samples at $105^{\circ} \mathrm{C}$ for at least $48 \mathrm{~h}$. After shaking the soil water liquid suspension for $30 \mathrm{~min}(1: 5 w / v)$, the soil $\mathrm{pH}$ was measured by an electrode $\mathrm{pH}$ meter (MT-5000, Shanghai, China). We used an elemental analyzer (Elementar, Germany) to determine the soil organic carbon (SOC) and total nitrogen. Nitrate nitrogen $\left(\mathrm{NO}_{3}{ }^{-}-\mathrm{N}\right)$ and ammonium nitrogen $\left(\mathrm{NH}_{4}{ }^{+} \mathrm{N}\right)$ levels were determined by an AA3 continuous flow analytical system with $1 \mathrm{M} \mathrm{KCl}$ extraction (SEAL AA3, Norderstedt, Germany). The soil total phosphorus (TP) and available phosphorus (AP) were determined by spectrophotometry after wet digestion with $\mathrm{HClO}_{4}-\mathrm{H}_{2} \mathrm{SO}_{4}$ and extracted with $0.5 \mathrm{M}$ $\mathrm{NaHCO}_{3}$ and measured with a spectrophotometer (Mapada Corporation, Shanghai, China). We used a Multi N/C 3100 Analyzer (Analytik Jena AG, Jena, Germany) to measure the soil dissolved organic carbon (DOC) and dissolved organic nitrogen (DON). Soil microbial biomass carbon $(\mathrm{MBC})$ and nitrogen $(\mathrm{MBN})$ were measured by the fumigation-extraction method [39].

\subsection{DNA Extraction and PCR Amplification}

We used an E.Z.N.A. ${ }^{\circledR}$ Soil DNA Kit (Omega Biotek, Norcross, GA, U.S.) to extract the bacterial and fungal DNA from the $0.5 \mathrm{~g}$ fresh soil samples. We used $1 \%$ agarose gels to check the quality and size of the extracted DNA using a NanoDrop 2000 spectrophotometer (Thermo Scientific, Wilmington, NC, USA). The primers 338F (5'-ACTCCTACGGGAGGCAGCAG-3') and 806R (5'-GGACTACHVGGGTWTCTAAT-3') were used to amplify $16 \mathrm{~S}$ genes for bacteria in the V3-V4 region. The primers ITS3F (5'-GCATCGATGAAGAACGCAGC-3') and ITS4R (5'-TCCTCCGCTTATTGATATGC-3') were used to amplify the ITS genes for fungi in the ITS2 region. All bacterial and fungal PCR amplifications were carried out with a thermal cycler PCR system (GeneAmp 9700, ABI, CA, USA). The detailed temperature cycle program was based on the description by Ji et al. [19].

\subsection{Illumina MiSeq Sequencing and Processing of the Sequencing Data}

A $2 \%$ agarose gel was used to extract the PCR products, which were then pooled together with equal molar amounts and then purified with an AxyPrep DNA Gel Extraction Kit (Axygen Biosciences, Union City, CA, USA). The products were quantified using a QuantiFluor ${ }^{\mathrm{TM}}$-ST fluorometer (Promega, Madison, WI, USA) based on the manufacturer's protocol. Then, the DNA amplicons were merged in equimolar amounts and paired-end sequenced on an Illumina MiSeq platform (Illumina, San Diego, CA, USA) $(2 \times 300 \mathrm{bp})$ following the standard protocols of Majorbio Bio-Pharm Technology Co., Ltd. (Shanghai, China). The original sequencing data are available from the NCBI database (bacterial accession number: PRJNA730331, fungal: PRJNA730332). 
We used Trimmomatic to demultiplex the raw fastq files and conduct quality filtering, and the reads were merged with FLASH [40]. We used UPARSE (version 7.1, http:/ / drive5 .com/uparse/, accessed on 16 July 2021) to cluster the sequences into operational taxonomic units (OTUs) based on 97\% similarity, and then identified and removed chimeric sequences using UCHIME. The taxonomic assignment of the 16S rRNA and ITS sequences was determined based on the bacterial SILVA reference database and fungal UNITE reference database using the RDP Classifier.

\subsection{Data Analysis}

The microbial community diversity was evaluated using the observed OTU number (Sobs) index, Shannon index, Simpson index, and Faith's PD index. After confirming that the data met the assumptions of homogeneity of variance and the normal distribution of residuals, the $t$-test was used to analyze the differences in soil properties, microbial diversity indices, and the relative abundance of microbial communities under different forest management practices. We used SPSS version 23.0 software (SPSS Inc., Chicago, IL, USA) for the analysis of variance. Principal coordinates analysis (PCoA) was performed to assess the microbial community structures in all plots based on the unweighted Unifrac distance. An analysis of similarities (ANOSIM) was performed to test for differences in the soil bacterial and fungal communities in different forest management regimes. Redundancy analysis (RDA) was conducted with the "vegan" package in R software. Before redundancy analysis, Monte Carlo permutations (999 repetitions) were used to identify soil parameters that were significantly correlated with variations in the microbial communities. The Mantel test was conducted using the mantel.rtest function in the "ade4" package in R.

\section{Results}

\subsection{Soil Physicochemical Properties}

Compared with $\mathrm{CK}$, the SOC, DOC, $\mathrm{NO}_{3}{ }^{-}-\mathrm{N}, \mathrm{C} / \mathrm{N}, \mathrm{AP}, \mathrm{MBC}$, and MBN in CTM plots increased by $18.5 \%, 15.3 \%, 18.8 \%, 40.5 \%, 30.1 \%, 64.2 \%$, and $32.3 \%$, respectively $(p<0.05$, Table 2). The content of TN in CTM plots was 19.8\% lower than in the CK. CTM practices had no significant effect on soil BD, moisture, $\mathrm{pH}$, or TP content $(p>0.05$, Table 2$)$.

Table 2. Soil physicochemical properties in a L. gmelinii plantation.

\begin{tabular}{|c|c|c|}
\hline \multirow{2}{*}{ Soil Properties } & \multicolumn{2}{|c|}{ Treatment } \\
\hline & CTM & CK \\
\hline $\mathrm{BD}\left(\mathrm{g} \cdot \mathrm{cm}^{-3}\right)$ & $0.84 \pm 0.09 \mathrm{~A}$ & $0.78 \pm 0.07 \mathrm{~A}$ \\
\hline Moisture (\%) & $23.00 \pm 0.74 \mathrm{~A}$ & $20.15 \pm 0.71 \mathrm{~A}$ \\
\hline $\mathrm{pH}$ & $5.89 \pm 0.04 \mathrm{~A}$ & $5.94 \pm 0.11 \mathrm{~A}$ \\
\hline $\operatorname{SOC}\left(\mathrm{g} \cdot \mathrm{kg}^{-1}\right)$ & $134.86 \pm 0.51 \mathrm{~A}$ & $113.68 \pm 0.40 \mathrm{~B}$ \\
\hline $\mathrm{TN}\left(\mathrm{g} \cdot \mathrm{kg}^{-1}\right)$ & $4.84 \pm 0.06 \mathrm{~B}$ & $5.70 \pm 0.12 \mathrm{~A}$ \\
\hline $\mathrm{C} / \mathrm{N}$ & $27.86 \pm 0.20 \mathrm{~A}$ & $19.94 \pm 0.20 \mathrm{~B}$ \\
\hline $\mathrm{TP}\left(\mathrm{g} \cdot \mathrm{kg}^{-1}\right)$ & $1.32 \pm 0.02 \mathrm{~A}$ & $1.55 \pm 0.04 \mathrm{~A}$ \\
\hline $\mathrm{AP}\left(\mathrm{mg} \cdot \mathrm{kg}^{-1}\right)$ & $33.65 \pm 1.55 \mathrm{~A}$ & $26.72 \pm 1.22 \mathrm{~B}$ \\
\hline $\mathrm{NO}_{3}{ }^{-}-\mathrm{N}\left(\mathrm{mg} \cdot \mathrm{kg}^{-1}\right)$ & $7.83 \pm 0.27 \mathrm{~A}$ & $6.59 \pm 0.93 \mathrm{~B}$ \\
\hline $\mathrm{NH}_{4}{ }^{+}-\mathrm{N}\left(\mathrm{mg} \cdot \mathrm{kg}^{-1}\right)$ & $75.43 \pm 7.53 \mathrm{~A}$ & $76.71 \pm 5.37 \mathrm{~A}$ \\
\hline $\mathrm{MBC}\left(\mathrm{mg} \cdot \mathrm{kg}^{-1}\right)$ & $964.91 \pm 40.83 \mathrm{~A}$ & $583.16 \pm 21.52 \mathrm{~B}$ \\
\hline $\mathrm{MBN}\left(\mathrm{mg} \cdot \mathrm{kg}^{-1}\right)$ & $35.44 \pm 0.09 \mathrm{~A}$ & $28.49 \pm 0.04 \mathrm{~B}$ \\
\hline $\mathrm{DOC}\left(\mathrm{mg} \cdot \mathrm{kg}^{-1}\right)$ & $150.13 \pm 10.32 \mathrm{~A}$ & $130.13 \pm 8.45 \mathrm{~B}$ \\
\hline $\mathrm{DON}\left(\mathrm{mg} \cdot \mathrm{kg}^{-1}\right)$ & $28.49 \pm 0.85 \mathrm{~B}$ & $35.44 \pm 1.16 \mathrm{~A}$ \\
\hline
\end{tabular}

CK, control treatment; CTM, crop tree management; BD, bulk density; SOC, soil organic carbon; TN, total nitrogen; $\mathrm{TP}$, total phosphorus; $\mathrm{AP}$, available phosphorus; $\mathrm{NO}_{3}{ }^{-}-\mathrm{N}$, nitrate nitrogen; $\mathrm{NH}_{4}{ }^{+}-\mathrm{N}$, ammonium nitrogen; MBC, microbial biomass carbon; MBN, microbial biomass nitrogen; DOC, dissolved organic carbon; DON, dissolved organic nitrogen; different upper letters indicate a significant difference between CTM and CK. 


\subsection{Summary of Soil Bacterial and Fungal Sequences}

The soil bacterial 16S rRNA and fungal ITS genes were analyzed by Illumina MiSeq sequencing. After filtering out the low-quality reads, a total of 364,237 high-quality bacterial sequences and 400,559 fungal sequences were obtained. The average read lengths for bacteria and fungi were 417 and $344 \mathrm{bp}$, respectively. A total of 54,171-67,029 (mean =60,706) soil bacterial and 51,750-74,437 (mean $=66,760$ ) soil fungal sequences were yielded per sample. The rarefaction curves of all the soil samples are shown in Figure S1.

\subsection{Soil Bacterial and Fungal $\alpha$ and $\beta$ Diversities in CTM}

Soil bacterial Sobs, Shannon, Simpson, and Faith's PD indices did not change significantly compared with CK plots ( $p>0.05$, Figure 1A-D). The Shannon and Simpson indices of soil fungi increased and decreased by $27 \%$ and $122 \%$ in CTM compared to CK, respectively $(p<0.05$, Figure $1 B, C)$. There were no significant variations in fungal Sobs or Faith's PD indices $(p>0.05$, Figure 1A,D).
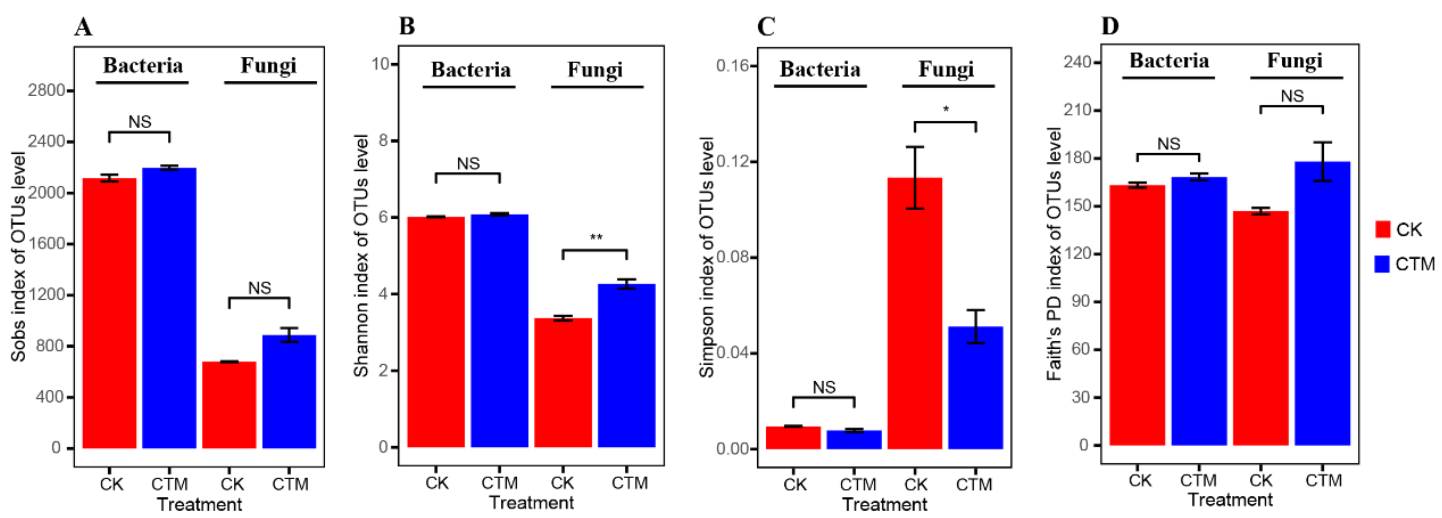

Figure 1. $\alpha$ diversity of soil bacterial and fungal communities in an L. gmelinii plantation after crop tree management. CTM, crop tree management. (A) observed number of OTUs (Sobs); (B) Shannon index; (C) Simpson index; (D) Faith's PD index. NS, not significant; ${ }^{*} p<0.05 ;{ }^{* *} p<0.01$.

Based on the Unweighted Unifrac distance, PCoA was performed on the soil bacterial and fungal sequencing data associated with the different forest management practices. For soil bacteria and fungi, the two principal coordinate axes explained more than $50 \%$ of the total variation in both bacterial and fungal community composition (Figure 2A,B). The samples were divided into two contrasting groups by forest management practice. The result of ANOSIM revealed that there was an obvious difference in the structures of the soil bacterial community between CK and CTM $(p<0.01$, Figure 2A).
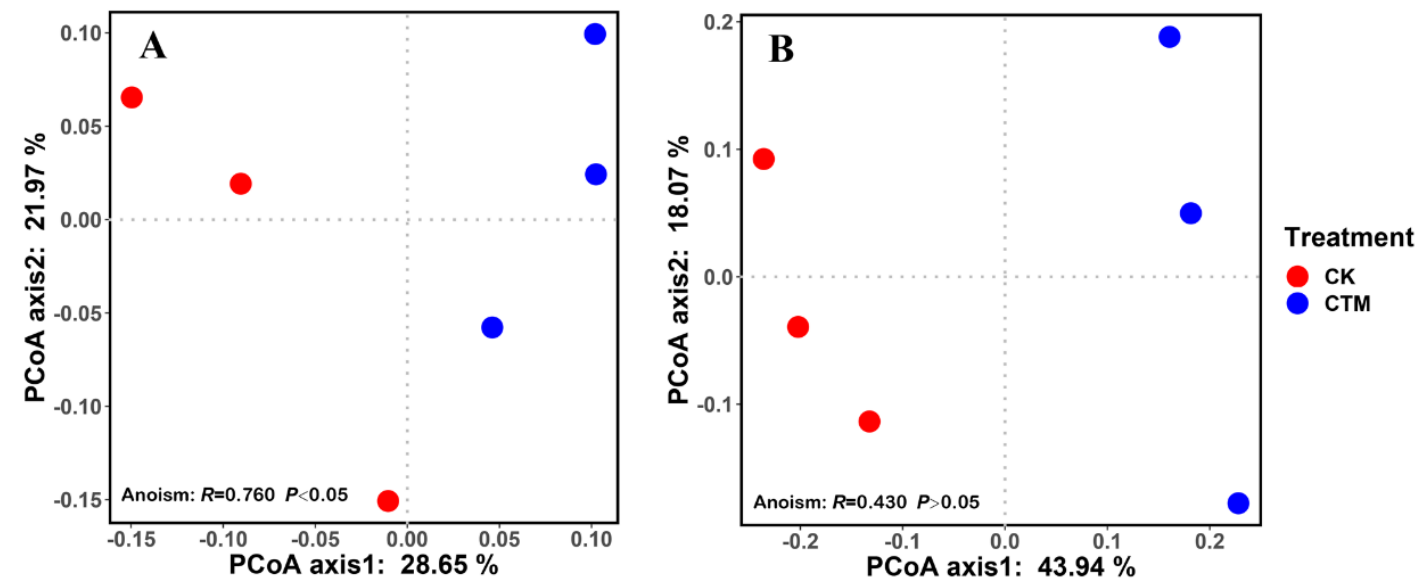

Figure 2. Principal coordinate analysis (PCoA) of the soil bacterial community (A) and fungal community (B) of an L. gmelinii plantation after crop tree management. 


\subsection{Soil Bacterial and Fungal Community Composition in CTM}

For soil bacteria, a total of 500 genera and 2910 OTUs were identified across all samples, distributed in 32 phyla and 87 classes. Proteobacteria, Actinobacteria, and Acidobacteria were the dominant phyla, with relative abundances of $30.7 \%, 22.1 \%$, and $16.7 \%$, respectively (Figure 3A). CTM had a significant effect on the relative abundances of Proteobacteria, Verrucomicrobia, and Chloroflexi ( $p<0.05$, Figure 3A, Table S1). At the class level, Actinobacteria, Alphaproteobacteria, and Verrucomicrobiae were the dominant classes, accounting for $52 \%$ of the total number of bacterial sequences obtained (Figure 3B). The relative abundance of Verrucomicrobiae in CTM was 78.2\% higher than in CK $(p<0.05$, Table S1). Compared with $\mathrm{CK}$, the relative abundances of Actinobacteria and Alphaproteobacteria were lower by $16.7 \%$ and $25.6 \%$ in CTM, respectively $(p<0.05$, Table S1).

A

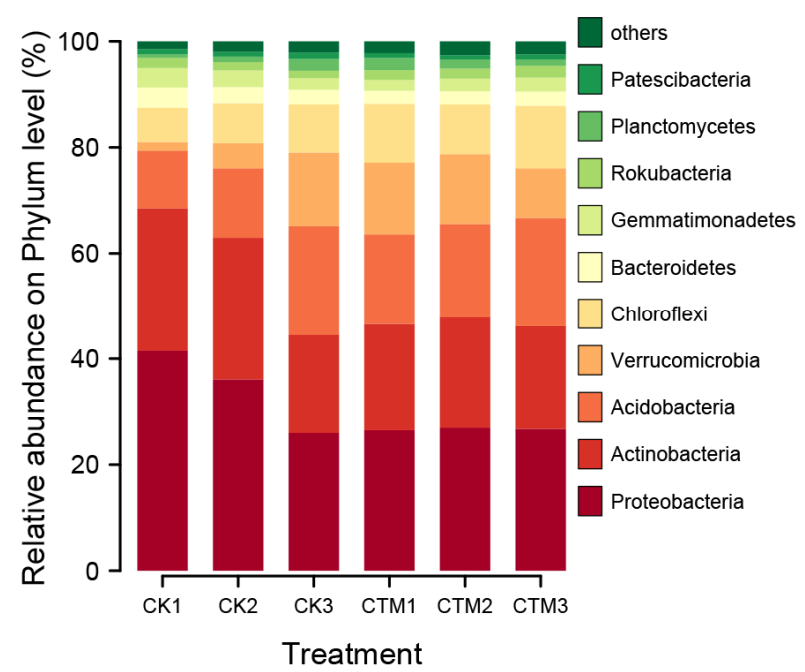

B

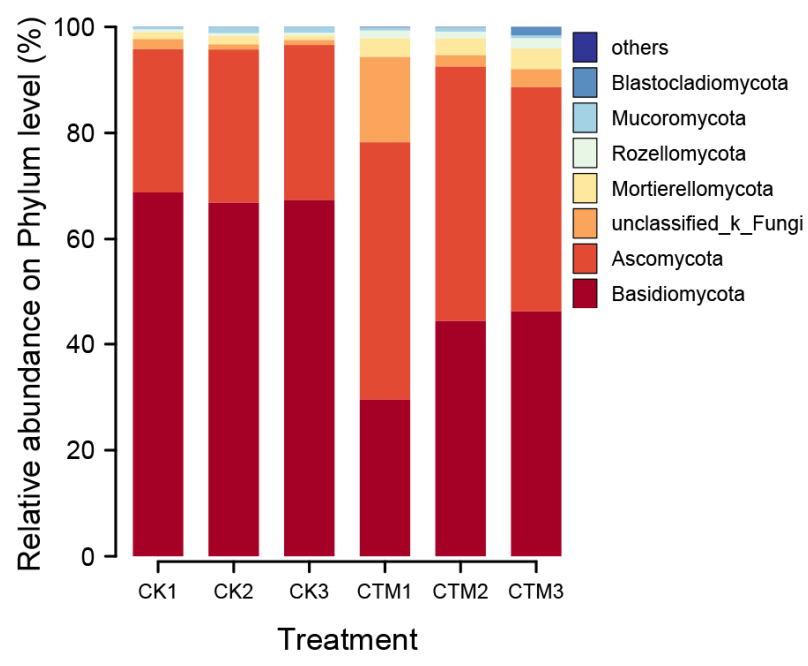

Figure 3. The relative abundance of soil bacterial (A) community and fungal (B) community in the phylum level of L. gmelinii plantation after crop tree management.

For soil fungi, a total of 396 genera and 1486 OTUs were identified, distributed in 13 phyla and 49 classes. Basidiomycota and Ascomycota were the dominant phyla, accounting for $88.1 \%$ of the total number of fungal sequences obtained $(p<0.05$, Figure $4 \mathrm{~A}$, Table S2). CTM had a significant effect on the relative abundances of Basidiomycota, Ascomycota, Mortierellomycota, and Rozellomycota. At the class level, Agaricomycetes, Leotiomycetes, and Pezizomycetes were the dominant classes, with the relative abundances of $51.4 \%, 15.9 \%$, and $7.5 \%$, respectively (Figure $4 \mathrm{~B}$ ). The relative abundance of Agaricomycetes in CTM was $43.3 \%$ lower than in CK $(p<0.05$, Table S2). Compared with CK, the relative abundances of Pezizomycetes and Sordariomycetes were higher by $151.4 \%$ and $81.8 \%$ in CTM, respectively ( $p<0.05$, Table S2).

\subsection{Shared and Unique OTUs}

The Venn diagram analysis showed that all samples shared 2532 bacterial OTUs and 798 fungal OTUs, which accounted for $87.0 \%$ and $53.7 \%$ of the total OTUs observed, respectively (Figure $5 \mathrm{~A}, \mathrm{~B})$. The amount of unique OTUs detected in the soil bacteria was lower than that of soil fungi. The proportions of unique OTUs of soil fungi in CTM and CK plots were $33.6 \%$ and $12.7 \%$, respectively (Figure $5 \mathrm{~B}$ ). 

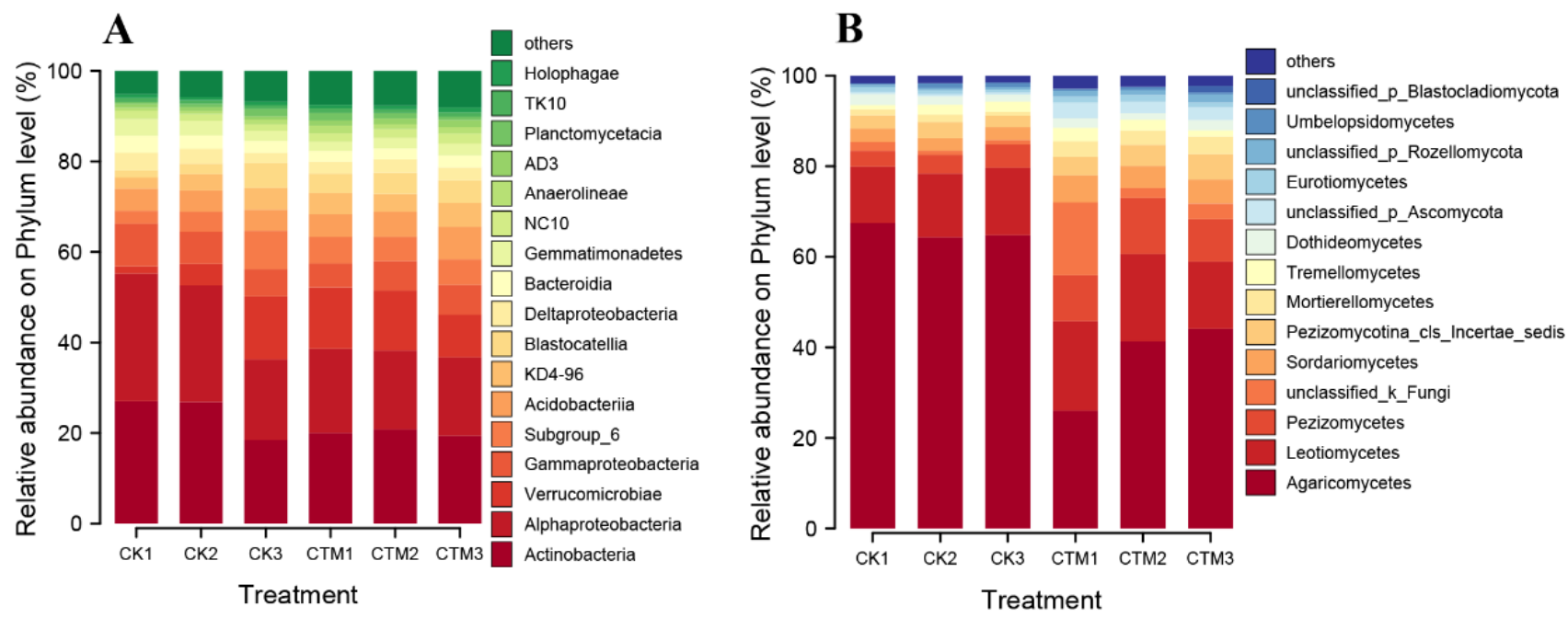

Figure 4. The relative abundance of soil bacterial (A) and fungal (B) communities at the class level in an L. gmelinii plantation after crop tree management.
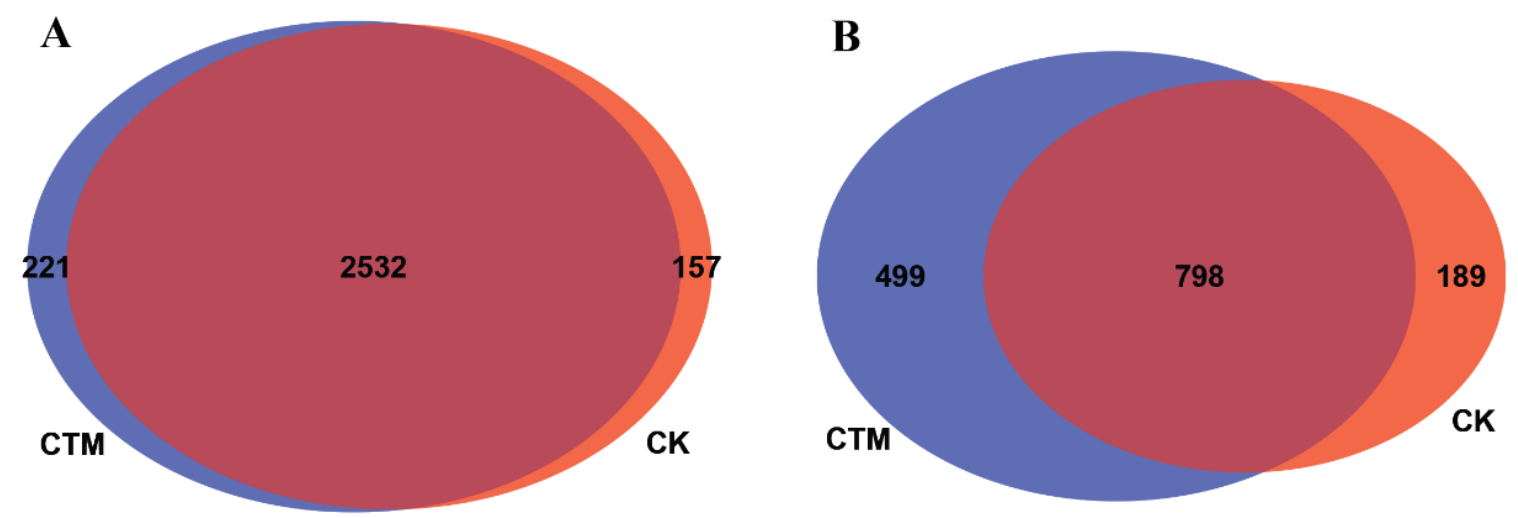

Figure 5. Venn diagram analyses of soil bacterial (A) and fungal (B) communities demonstrating the numbers of shared and unique observed OTUs at $97 \%$ similarity.

\subsection{Relationships between Soil Microbial Communities and Soil Properties}

We used RDA and the Mantel test to evaluate the relationships between the soil properties and microbial community. The ordination diagram demonstrated that the first two axes explained more than $90 \%$ of the variation in the bacterial and fungal community structure (Figure 6A,B). The Mantel test showed that soil bacterial community composition was significantly correlated with the contents of DOC, soil moisture, and TP (Table 3; $R^{2} \mathrm{DOC}=0.914$, $P_{\mathrm{DOC}}=0.009 ; R^{2}$ moisture $=0.873, P_{\text {moisture }}=0.016$; and $R_{\mathrm{TP}}^{2}=0.758, P_{\mathrm{TP}}=0.026$, respectively). For the fungal soil community, the contents of soil DON, TP, and C/N were the main factors influencing their community compositions (Table $3 ; R^{2} \mathrm{DON}=0.865, P_{\mathrm{DON}}=0.008$; $R^{2} \mathrm{TP}=0.717, P_{\mathrm{TP}}=0.022 ;$ and $R^{2} \mathrm{C} / \mathrm{N}=0.703, P_{\mathrm{C} / \mathrm{N}}=0.037$, respectively). 

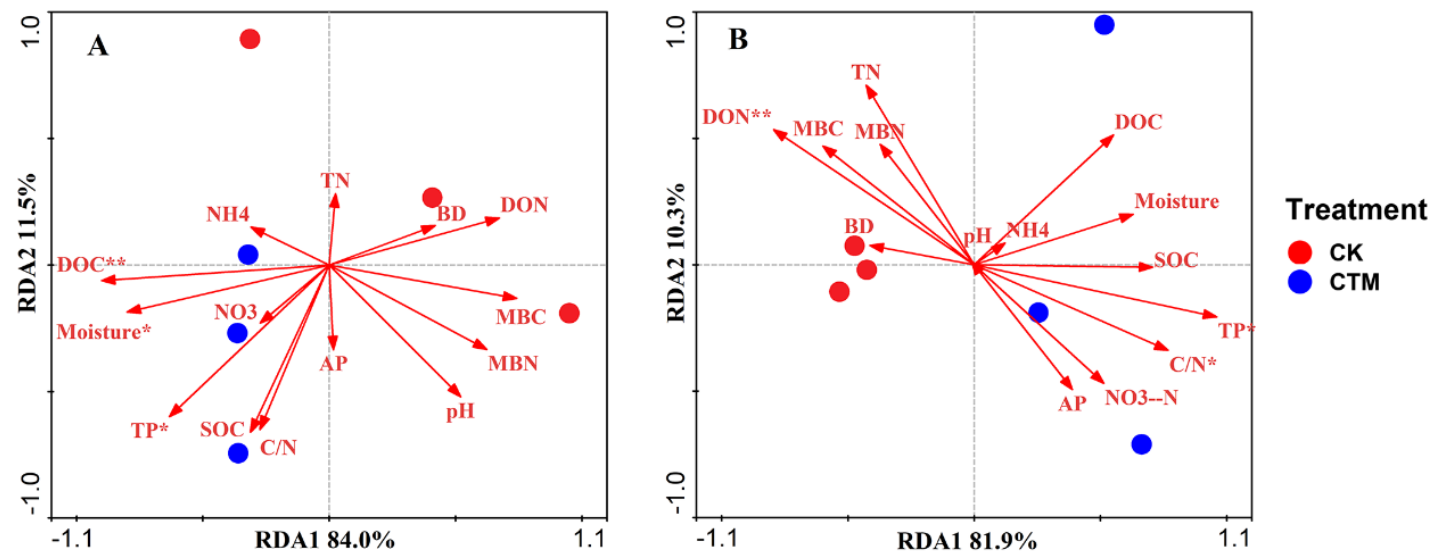

Figure 6. RDA of soil bacterial (A) and fungal (B) communities at the genus level and soil physical and chemical properties. $\mathrm{BD}$, bulk density; SOC, soil organic carbon; $\mathrm{TN}$, total nitrogen; $\mathrm{TP}$, total phosphorus; $\mathrm{AP}$, available phosphorus; $\mathrm{NO}_{3}{ }^{-}-\mathrm{N}$, nitrate nitrogen; $\mathrm{NH}_{4}{ }^{+}-\mathrm{N}$, ammonium nitrogen; $\mathrm{MBC}$, microbial biomass carbon; $\mathrm{MBN}$, microbial biomass nitrogen; DOC, dissolved organic carbon; DON, dissolved organic nitrogen; ${ }^{*} p<0.05$; ${ }^{* *} p<0.01$.

Table 3. Mantel test results for the correlation between microbial community composition and soil factors at the genus level.

\begin{tabular}{ccccc}
\hline \multirow{2}{*}{ Soil Variable } & \multicolumn{2}{c}{ Bacteria } & \multicolumn{2}{c}{ Fungi } \\
\cline { 2 - 5 } & $\boldsymbol{R}^{\mathbf{2}}$ & $\boldsymbol{p}$ & $\boldsymbol{R}^{\mathbf{2}}$ & $\boldsymbol{p}$ \\
\hline $\mathrm{BD}$ & 0.199 & 0.719 & 0.175 & 0.722 \\
Moisture & 0.873 & $\mathbf{0 . 0 1 6}$ & 0.436 & 0.436 \\
$\mathrm{pH}$ & 0.541 & 0.311 & 0.003 & 1.000 \\
$\mathrm{SOC}$ & 0.534 & 0.309 & 0.500 & 0.370 \\
$\mathrm{TN}$ & 0.080 & 0.855 & 0.587 & 0.227 \\
$\mathrm{TP}$ & 0.758 & $\mathbf{0 . 0 2 6}$ & 0.717 & $\mathbf{0 . 0 2 2} *$ \\
$\mathrm{C} / \mathrm{N}$ & 0.497 & 0.356 & 0.703 & $\mathbf{0 . 0 3 7}$ \\
$\mathrm{AP}$ & 0.112 & 0.847 & 0.394 & 0.518 \\
$\mathrm{NO}_{3}{ }^{-}-\mathrm{N}$ & 0.127 & 0.801 & 0.483 & 0.333 \\
$\mathrm{NH}_{4}{ }^{-}-\mathrm{N}$ & 0.117 & 0.816 & 0.022 & 0.952 \\
$\mathrm{MBC}$ & 0.567 & 0.297 & 0.579 & 0.305 \\
$\mathrm{MBN}$ & 0.498 & 0.354 & 0.365 & 0.500 \\
$\mathrm{DOC}$ & 0.914 & $\mathbf{0 . 0 0 9} * *$ & 0.567 & 0.290 \\
$\mathrm{DON}$ & 0.487 & 0.093 & 0.865 & $\mathbf{0 . 0 0 8}$
\end{tabular}

BD, bulk density; $\mathrm{SOC}$, soil organic carbon; TN, total nitrogen; TP, total phosphorus; $\mathrm{AP}$, available phosphorus, $\mathrm{NO}_{3}{ }^{-}-\mathrm{N}$, nitrate nitrogen; $\mathrm{NH}_{4}{ }^{+}-\mathrm{N}$, ammonium nitrogen; $\mathrm{MBC}$, microbial biomass carbon; $\mathrm{MBN}$, microbial biomass nitrogen; DOC, dissolved organic carbon; DON, dissolved organic nitrogen; ${ }^{*} p<0.05 ;{ }^{* *}, p<0.01$. Values in bold type indicate significant effects.

\section{Discussion}

Our results emphasize several key findings associated with the impact of the shortterm CTM of larch plantations in boreal forest ecosystems on soil bacterial and fungal communities. Firstly, the divergent responses of soil bacterial and fungal diversity were observed with CTM practices. The Shannon and Simpson indices of soil fungi increased and decreased after CTM, respectively, but we observed no obvious variation in those of soil bacteria. In addition, after the five years of continued CTM, the relative abundances of the dominant phyla and classes of soil bacteria and fungi were dramatically changed; however, the community composition of soil bacteria was similar between CK and CTM plots but reached a significant difference in soil fungi. We found a higher proportion of unique OTUs of soil fungi with CTM. Finally, the variation in soil factors that were significantly affected by CTM practices led to the divergent response of bacterial and fungal communities to forest management. 


\subsection{Response of Soil Bacterial and Fungal Community Composition to CTM}

Addressing our first hypothesis, we found that CTM practice had a significant effect on the dominant soil bacterial (Proteobacteria, Actinobacteria, and Acidobacteria) and fungal (Basidiomycota and Ascomycota) phyla - a finding in line with those of Wan et al. [41] and Wang et al. [42]. Proteobacteria and Acidobacteria are considered eutrophic and oligotrophic bacterial phyla [43,44], respectively; Actinobacteria, as an important member of the bacteria, exerted critical functions in organic matter transformation and the carbon cycle [45]. In this study, the relative abundance of Proteobacteria was higher in all plots than that of Acidobacteria, which indicated the soil condition was rich. In addition, CTM practices significantly decreased the relative abundance of Proteobacteria, illustrating the decreasing soil nutrient level caused by the interference due to short-term CTM. Basidiomycota and Ascomycota can decompose recalcitrant soil organic matter (e.g., lignin and chitin) and are the main drivers for nutrient cycles and energy flows [46]. We observed that the relative abundances of Basidiomycota and Ascomycota were 63.7\% higher and $40.8 \%$ lower in CTM than in CK, respectively, which is in line with the results reported by Hartmann et al. [47] and Wan et al. [41]. Agaricomycetes, as the dominant class in coniferous forests, are members of ectomycorrhizal fungi related to the growth of coniferous trees. In this study, CTM improved the relative abundance of Agaricomycetes. A possible explanation for this might be that removing interfering trees leads to a decrease in litter and root input and an increase in the species richness of the understory, subsequently improving the relative abundance of Ascomycota. Our results emphasize that the variations in soil bacterial and fungal communities are affected by forest structure and plant coverage caused by CTM, which is consistent with previously reported results $[48,49]$.

\subsection{Divergent Impacts of CTM on Soil Bacterial and Fungal Communities}

Previous studies found that forest management practices improved the diversity of the understory, accelerated the soil nutrient cycle, and increased the microbial diversity and biomass [22,50-53]. Additionally, forest management practices shaped the soil microenvironment and promoted secretions of root exudates and the decomposition of litter, which influenced the quality and quantity of soil organic matter and affected soil microbial community structure [54-57]. In this study, soil fungal Shannon and Simpson indices were increased and decreased by CTM, respectively, while soil bacterial $\alpha$ diversity was not significantly different between CTM and CK, which partially supports our first hypothesis. Urbanová et al. [55] found that the community structure and diversity of soil bacteria were largely determined by the tree species. The dominant tree species was larch in both forest stands, the compositions of trees and litter under short-term CTM did not change significantly, and the soil bacterial community diversity did not show significant differences between CK and CTM plots. This finding is consistent with the results of Dang et al. [22] and Zhou et al. [33]. Furthermore, the bacterial community has a narrow niche in the soil and is rarely mutualistically symbiotic with plants [58]. In addition, after short-term CTM, the herbaceous diversity significantly increased (data not shown), which might provide a reasonable explanation for the increase in fungal community diversity. Interestingly, contrary to our second hypothesis, we found that soil bacterial $\beta$ diversity was more sensitive to CTM than that of soil fungi. Accordingly, CTM practices had a significant effect on the relative abundances of the dominant phyla and classes in the soil. Zhou et al. [33] indicated that thinning could explain the $59 \%$ variation in the soil fungal community composition in a larch plantation but had no significant effect on that of soil bacteria. We speculate that this inconsistent result was caused by the stand age and long-term thinning. Overall, short-term CTM had a profound effect on the fungal $\alpha$ diversity and bacterial $\beta$ diversity.

\subsection{Soil Bacterial and Fungal Community Compositions Mediated by Soil Factors}

Soil physicochemical properties are closely associated with the soil microbial community structure, affecting the stability and differences in the microbial community structure $[59,60]$. Soil microbes can promote the accumulation of soil nutrients via decomposing 
litter, which is an important pathway to improve soil properties [61,62]. In this study, the result of the Mantel test showed that the TP content was closely related to both the soil bacterial fungal community compositions. Lauber et al. [63] found that phosphorus-rich soil had a higher microbial abundance compared with phosphorus-poor soil. Soil moisture affects the soil microbial biomass and community composition by changing the use of soil resources [20]. Shihan et al. [64] revealed that higher soil moisture conditions could provide a favorable environment for litter decomposition and microbial inhabitation and increase the ability of soil bacterial communities to metabolize substrates. Dissolved organic matter, as an important component of soil organic matter, provides substrates and resources for heterotrophic microorganisms [65-67]. Huang et al. [67], in a recent study, indicated that the quality of DOM was the key factor driving soil fungal diversity and community compositions. In this study, DOC and DON affected the soil bacteria and fungi community compositions, respectively. Soil dissolved organic matter is mainly derived from soil humus and litter decomposition, plant roots, and soil microbial secretion; also, soil DOC and DON are soil labile substances and easily used by soil microorganisms [68]. In addition, our results showed that soil $\mathrm{C} / \mathrm{N}$ was another driving factor affecting the soil fungi community: soil substrates with a higher $\mathrm{C} / \mathrm{N}$ may be rich in lignin and polyphenols, which can induce the growth of specific fungi groups [69,70]. Hackl et al. [71] evaluated variations in the relative abundances of the fungal communities in 12 forest types and found that organic matter in coniferous forest soil had a high $\mathrm{C} / \mathrm{N}$. They speculated that specific fungal groups could adapt to a high $\mathrm{C} / \mathrm{N}$ in coniferous forest soil due to the transformation of more soil organic carbon via their hyphae. Our results further support our third hypothesis- that is, the impact of CTM on the soil microenvironment is the main cause of changing soil bacterial and fungal communities.

\section{Conclusions}

In this study, we aimed to evaluate the impact of short-term CTM on soil bacterial and fungal community structures. Our results showed that short-term CTM practices for a Larix gmelinii plantation significantly promoted the soil fungal $\alpha$ diversity (Shannon and Simpson indices) but had no significant effect on the soil bacterial $\alpha$ diversity. However, the bacterial $\beta$ diversity was more sensitive to CTM than that of soil fungi. The dramatic variations in soil factors caused by CTM dominated the relative abundance and diversity of the soil's bacterial and fungal communities in the Larix gmelinii plantation. The soil DOC, moisture, and TP significantly affected the bacterial community composition, while soil DON, C/N, and total phosphorus affected the variations in the fungal community. Despite the results of this study providing important insights into the impact of short-term CTM on soil microbial communities, we still need to understand the basic information of microbial communities for different forest development statuses. In addition, we only considered monoculture forests in this study; considerably more work will need to be undertaken to determine and evaluate the effect of CTM in mixed forests. The precise mechanism of CTM in the near-natural forest management of Larix gmelinii plantation remains to be elucidated.

Supplementary Materials: The following are available online at https: / www.mdpi.com/article / 10.3390/f12101411/s1, Table S1: T-test of the relative abundance of dominant bacterial phyla and classes, Table S2: $T$-test of the relative abundance of dominant fungal phyla and classes, Figure S1: Rarefaction curves of the number of operational taxonomic units (OTUs) for soil bacterial (A) and fungal (B) communities at $97 \%$ sequence similarity. CTM, crop tree management.

Author Contributions: L.J. and L.Y. conceived and designed the original study idea; L.J., J.Y., X.Z. and Y.L. performed experimental work, sampling, and DNA sequencing; L.J. carried out the bioinformatics and statistical analysis; L.J. created the figures and wrote the manuscript; L.J. and L.Y. provided funding. All authors helped to edit and complete the manuscript. All authors have read and agreed to the published version of the manuscript. 
Funding: This work was financially supported by the Fundamental Research Funds for the Central Universities (2572019AA07; 2572019CP16; 2572020DR05), and the Heilongjiang Touyan Innovation Team Program (Technology Development Team for Highly efficient Silviculture of Forest Resources).

Institutional Review Board Statement: Not applicable.

Informed Consent Statement: Not applicable.

Data Availability Statement: The data presented in this study are available on request from the corresponding author.

Acknowledgments: We are grateful to Huifeng Liu and the Nancha Forestry Bureau for access permission and valuable field assistance. We also thank Yan Zhang and Yujiao Wang for assistance with laboratory analyses. Li Ji thanks for the scholarship supported by the China Scholarship Council (No. 201906600038).

Conflicts of Interest: The authors declare no conflict of interest.

\section{References}

1. Kotar, M. Sustainable and multipurpose forest management with production of high quality timber. Nat.-Based For. Cent. Eur. 2006, 126, 153-167.

2. Larsen, J.; Nielsen, A. Nature-based forest management-Where are we going?: Elaborating forest development types in and with practice. For. Ecol. Manag. 2007, 238, 107-117. [CrossRef]

3. Kang, J.-S.; Shibuya, M.; Shin, C.-S. The effect of forest-thinning works on tree growth and forest environment. For. Sci. Technol. 2014, 10, 33-39. [CrossRef]

4. Perkey, A.W. Crop Tree Management in Eastern Hardwoods; United States Department of Agriculture, Forest Service, Northeastern Area State and Private Forestry: Morgantown, WV, USA, 1994.

5. Miller, G.W.; Stringer, J.W.; Mercker, D.C. Technical guide to crop tree release in hardwood forests. Publication PB1774; University of Tennessee Extension: Knoxville, TN, USA, 2007; 24p, [Published with the University of Kentucky Cooperative Extension and Southern Regional Extension Forestry].

6. Abetz, P.; Klädtke, J. The Target Tree Management System. Die Z-Baum-Kontrollmethode. Eur. J. For. Res. 2002, 121, 73-82. [CrossRef]

7. Lu, Y.C. Theory and Practice of Near-Natural Forest Management; Science Press: Beijing, China, 2006.

8. Porté, A.; Bartelink, H. Modelling mixed forest growth: A review of models for forest management. Ecol. Model. 2002, 150, 141-188. [CrossRef]

9. Miller, G.W.; Stringer, J.W. Effect of crown release on tree grade and dbh growth of white oak sawtimber in eastern kentucky. In Proceedings of the 14th Central Hardwood Forest Conference, Wooster, OH, USA, 16-19 March 2004; Gen. Tech. Rep. NE-316. Yaussy, D.A., Hix, D.M., Long, R.P., Goebel, P.C., Eds.; US Department of Agriculture, Forest Service, Northeastern Research Station: Newtown Square, PA, USA, 2004; pp. 37-44.

10. Gómez-Aparicio, L.; García-Valdés, R.; Ruiz-Benito, P.; Zavala, M.A. Disentangling the relative importance of climate, size and competition on tree growth in Iberian forests: Implications for forest management under global change. Glob. Chang. Biol. 2011, 17, 2400-2414. [CrossRef]

11. Collado, E.; Camarero, J.J.; de Aragón, J.M.; Pemán, J.; Bonet, J.A.; de-Miguel, S. Linking fungal dynamics, tree growth and forest management in a mediterranean pine ecosystem. For. Ecol. Manag. 2018, 422, 223-232. [CrossRef]

12. Bawa, K.S.; Seidler, R. Natural forest management and conservation of biodiversity in tropical forests. Conserv. Biol. 1998, 12, 46-55. [CrossRef]

13. Verschuyl, J.; Riffell, S.; Miller, D.; Wigley, T.B. Biodiversity response to intensive biomass production from forest thinning in North American forests-A meta-analysis. For. Ecol. Manag. 2011, 261, 221-232. [CrossRef]

14. Lv, Q.; Yin, H.; He, P.; Li, X.; Fan, C.; Feng, M.; Liu, J.; Wang, Y. Effects of early management of pinus massoniana plantation target trees on soil physicochemical properties and plant diversity. Chin. J. Appl. Environ. Biol. 2018, 3, 500-507.

15. Li, X.; Su, Y.; Yin, H.; Liu, S.; Chen, G.; Fan, C.; Feng, M.; Li, X. The Effects of Crop Tree Management on the Fine Root Traits of Pinus massoniana in Sichuan Province, China. Forests 2020, 11, 351. [CrossRef]

16. Yin, H.; Su, Y.; Li, X.; Fan, C.; Chen, G.; Feng, M.; Liu, S.; Guo, M.; Li, X.; Chen, Y.; et al. Crop tree release increased the density of soil nematodes and improved the food web structure. Can. J. For. Res. 2021, 51, 101-110. [CrossRef]

17. Ullah, N.; Ditta, A.; Khalid, A.; Mehmood, S.; Rizwan, M.S.; Ashraf, M.; Mubeen, F.; Imtiaz, M.; Iqbal, M.M. Integrated effect of algal biochar and plant growth promoting rhizobacteria on physiology and growth of maize under deficit irrigations. J. Soil Sci. Plant Nutr. 2019, 20, 346-356. [CrossRef]

18. Ji, L.; Yang, Y.; Yang, L. Effect of land uses on soil microbial community structures among different soil depths in northeastern China. Eur. J. Soil Biol. 2020, 99, 103205. [CrossRef]

19. Ji, L.; Yang, Y.; Yang, L. Seasonal variations in soil fungal communities and co-occurrence networks along an altitudinal gradient in the cold temperate zone of China: A case study on Oakley Mountain. Catena 2021, 204, 105448. [CrossRef] 
20. Brockett, B.F.; Prescott, C.E.; Grayston, S.J. Soil moisture is the major factor influencing microbial community structure and enzyme activities across seven biogeoclimatic zones in western Canada. Soil Biol. Biochem. 2012, 44, 9-20. [CrossRef]

21. Ramirez, K.S.; Craine, J.M.; Fierer, N. Consistent effects of nitrogen amendments on soil microbial communities and processes across biomes. Glob. Chang. Biol. 2012, 18, 1918-1927. [CrossRef]

22. Dang, P.; Gao, Y.; Liu, J.; Yu, S.; Zhao, Z. Effects of thinning intensity on understory vegetation and soil microbial communities of a mature Chinese pine plantation in the Loess Plateau. Sci. Total. Environ. 2018, 630, 171-180. [CrossRef]

23. Kim, S.; Li, G.; Han, S.H.; Kim, H.-J.; Kim, C.; Lee, S.-T.; Son, Y. Thinning affects microbial biomass without changing enzyme activity in the soil of Pinus densiflora Sieb. et Zucc. forests after 7 years. Ann. For. Sci. 2018, 75, 13. [CrossRef]

24. Richter, A.; Schöning, I.; Kahl, T.; Bauhus, J.; Ruess, L. Regional environmental conditions shape microbial community structure stronger than local forest management intensity. For. Ecol. Manag. 2018, 409, 250-259. [CrossRef]

25. Kim, S.; Li, G.; Han, S.H.; Kim, C.; Lee, S.-T.; Son, Y. Microbial biomass and enzymatic responses to temperate oak and larch forest thinning: Influential factors for the site-specific changes. Sci. Total Environ. 2018, 651, 2068-2079. [CrossRef]

26. Zhou, T.; Wang, C.; Zhou, Z. Impacts of forest thinning on soil microbial community structure and extracellular enzyme activities: A global meta-analysis. Soil Biol. Biochem. 2020, 149, 107915. [CrossRef]

27. Bastida, F.; López-Mondéjar, R.; Baldrian, P.; Andrés-Abellán, M.; Jehmlich, N.; Torres, I.; García, C.; López-Serrano, F. When drought meets forest management: Effects on the soil microbial community of a Holm oak forest ecosystem. Sci. Total Environ. 2019, 662, 276-286. [CrossRef] [PubMed]

28. Chen, X.; Wang, D.; Wang, J.; Diao, J.-J.; Zhang, J.-Y.; Guan, Q.-W. Soil microbial functional diversity and biomass as affected by different thinning intensities in a Chinese fir plantation. Appl. Soil Ecol. 2015, 92, 35-44. [CrossRef]

29. Blanco, J.A.; Imbert, J.B.; Castillo, F.J. Nutrient return via litterfall in two contrasting Pinus sylvestris forests in the Pyrenees under different thinning intensities. For. Ecol. Manag. 2008, 256, 840-1852. [CrossRef]

30. Vadeboncoeur, M.; Hamburg, S.P.; Yanai, R.D.; Blum, J.D. Rates of sustainable forest harvest depend on rotation length and weathering of soil minerals. For. Ecol. Manag. 2014, 318, 194-205. [CrossRef]

31. Yang, B.; Pang, X.; Hu, B.; Bao, W.; Tian, G. Does thinninginduced gap size result in altered soil microbial community in pine plantation in eastern Tibetan Plateau? Ecol. Evol. 2017, 7, 2986-2993. [CrossRef]

32. De Boer, W.; Folman, L.B.; Summerbell, R.C.; Boddy, L. Living in a fungal world: Impact of fungi on soil bacterial niche development. FEMS Microbiol. Rev. 2005, 29, 795-811. [CrossRef]

33. Zhou, Z.; Wang, C.; Ren, C.; Sun, Z. Effects of thinning on soil saprotrophic and ectomycorrhizal fungi in a Korean larch plantation. For. Ecol. Manag. 2020, 461, 117920. [CrossRef]

34. Kohout, P.; Charvátová, M.; Štursová, M.; Mašínová, T.; Tomsovsky, M.; Baldrian, P. Clearcutting alters decomposition processes and initiates complex restructuring of fungal communities in soil and tree roots. ISME J. 2018, 12, 692-703. [CrossRef]

35. Yang, K.; Zhu, J.-J.; Yan, Q.-L.; Sun, O. Changes in soil P chemistry as affected by conversion of natural secondary forests to larch plantations. For. Ecol. Manag. 2010, 260, 422-428. [CrossRef]

36. Yang, K.; Zhu, J.; Xu, S.; Zheng, X. Conversion from temperate secondary forests into plantations (Larix spp.): Impact on belowground carbon and nutrient pools in northeastern China. Land Degrad. Dev. 2018, 29, 4129-4139. [CrossRef]

37. Zak, D.R.; Holmes, W.E.; White, D.C.; Peacock, A.D.; Tilman, D. Plant diversity, soil microbial communities, and ecosystem function: Are there any links? Ecology 2003, 84, 2042-2050. [CrossRef]

38. López-Mondéjar, R.; Brabcová, V.; Štursová, M.; Davidová, A.; Jansa, J.; Cajthaml, T.; Baldrian, P. Decomposer food web in a deciduous forest shows high share of generalist microorganisms and importance of microbial biomass recycling. ISME J. 2018, 12, 1768-1778. [CrossRef]

39. Brookes, P.; Landman, A.; Pruden, G.; Jenkinson, D. Chloroform fumigation and the release of soil nitrogen: A rapid direct extraction method to measure microbial biomass nitrogen in soil. Soil Biol. Biochem. 1985, 17, 837-842. [CrossRef]

40. Caporaso, J.G.; Lauber, C.L.; Walters, W.A.; Berg-Lyons, D.; Huntley, J.; Fierer, N.; Owens, S.; Betley, J.; Fraser, L.; Bauer, M.; et al. Ultra-high-throughput microbial community analysis on the Illumina HiSeq and MiSeq platforms. ISME J. 2012, 6, $1621-1624$. [CrossRef]

41. Wan, P.; Zhang, G.; Zhao, Z.; Hu, Y.; Liu, W.; Hui, G. Short-Term Effects of Different Forest Management Methods on Soil Microbial Communities of a Natural Quercus aliena var. acuteserrata Forest in Xiaolongshan, China. Forests 2019, 10, 161. [CrossRef]

42. Wang, C.; Xue, L.; Dong, Y.; Jiao, R. Effects of stand density on soil microbial community composition and enzyme activities in subtropical Cunninghamia lanceolate (Lamb.) Hook plantations. For. Ecol. Manag. 2020, 479, 118559. [CrossRef]

43. Fierer, N.; Bradford, M.; Jackson, R.B. Toward an ecological classification of soil bacteria. Ecology 2007, 88, 1354-1364. [CrossRef]

44. Liu, J.; Sui, Y.; Yu, Z.; Yao, Q.; Shi, Y.; Chu, H.; Jin, J.; Liu, X.; Wang, G. Diversity and distribution patterns of acidobacterial communities in the black soil zone of northeast China. Soil Biol. Biochem. 2016, 95, 212-222. [CrossRef]

45. Zheng, J.; Chen, J.; Pan, G.; Wang, G.; Liu, X.; Zhang, X.; Li, L.; Bian, R.; Cheng, K.; Zheng, J. A long-term hybrid poplar plantation on cropland reduces soil organic carbon mineralization and shifts microbial community abundance and composition. Appl. Soil Ecol. 2017, 111, 94-104. [CrossRef]

46. Ma, A.; Zhuang, X.; Wu, J.; Cui, M.; Lv, D.; Liu, C.; Zhuang, G. Ascomycota Members Dominate Fungal Communities during Straw Residue Decomposition in Arable Soil. PLoS ONE 2013, 8, e66146. [CrossRef] 
47. Hartmann, M.; Howes, C.G.; VanInsberghe, D.; Yu, H.; Bachar, D.; Christen, R.; Nilsson, R.H.; Hallam, S.J.; Mohn, W.W. Significant and persistent impact of timber harvesting on soil microbial communities in Northern coniferous forests. ISME J. 2012, 6, 2199-2218. [CrossRef]

48. Macdonald, C.; Thomas, N.; Robinson, L.; Tate, K.R.; Ross, D.J.; Dando, J.; Singh, B.K. Physiological, biochemical and molecular responses of the soil microbial community after afforestation of pastures with Pinus radiata. Soil Biol. Biochem. 2009, 41, 1642-1651. [CrossRef]

49. Dang, P.; Yu, X.; Le, H.; Liu, J.; Shen, Z.; Zhao, Z. Effects of stand age and soil properties on soil bacterial and fungal community composition in Chinese pine plantations on the Loess Plateau. PLoS ONE 2017, 12, e0186501. [CrossRef]

50. Rab, M. Soil physical and hydrological properties following logging and slash burning in the Eucalyptus regnans forest of southeastern australia. For. Ecol. Manage. 1996, 84, 159-176. [CrossRef]

51. Pang, X.; Bao, W.; Zhu, B.; Cheng, W. Responses of soil respiration and its temperature sensitivity to thinning in a pine plantation. Agric. For. Meteorol. 2013, 171-172, 57-64. [CrossRef]

52. Zhou, X.; Zhou, Y.; Zhou, C.; Wu, Z.; Zheng, L.; Hu, X.; Chen, H.; Gan, J. Effects of cutting intensity on soil physical and chemical properties in a mixed natural forest in southeastern China. Forests 2015, 6, 4495-4509. [CrossRef]

53. Zhou, L.; Cai, L.; He, Z.; Wang, R.; Wu, P.; Ma, X. Thinning increases understory diversity and biomass, and improves soil properties without decreasing growth of Chinese fir in southern China. Environ. Sci. Pollut. Res. 2016, 23, 24135-24150. [CrossRef] [PubMed]

54. Prescott, C.E.; Grayston, S.J. Tree species influence on microbial communities in litter and soil: Current knowledge and research needs. For. Ecol. Manag. 2013, 309, 19-27. [CrossRef]

55. Urbanová, M.; Šnajdr, J.; Baldrian, P. Composition of fungal and bacterial communities in forest litter and soil is largely determined by dominant trees. Soil Biol. Biochem. 2015, 84, 53-64. [CrossRef]

56. Zwetsloot, M.J.; Kessler, A.; Bauerle, T.L. Phenolic root exudate and tissue compounds vary widely among temperate forest tree species and have contrasting effects on soil microbial respiration. New Phytol. 2018, 218, 530-541. [CrossRef]

57. Chen, L.; Xiang, W.; Wu, H.; Ouyang, S.; Lei, P.; Hu, Y.; Ge, T.; Ye, J.; Kuzyakov, Y. Contrasting patterns and drivers of soil fungal communities in subtropical deciduous and evergreen broadleaved forests. Appl. Microbiol. Biotechnol. 2019, 103, 5421-5433. [CrossRef]

58. Sun, S.; Li, S.; Avera, B.N.; Strahm, B.D.; Badgley, B.D. Soil bacterial and fungal communities show distinct recovery patterns during forest ecosystem restoration. Appl. Environ. Microbiol. 2017, 83, e00966-17. [CrossRef]

59. Štursová, M.; Bárta, J.; Šantrůčková, H.; Baldrian, P. Small-scale spatial heterogeneity of ecosystem properties, microbial community composition and microbial activities in a temperate mountain forest soil. FEMS Microbiol. Ecol. 2016, 92. [CrossRef] [PubMed]

60. Lladó, S.; López-Mondéjar, R.; Baldrian, P. Drivers of microbial community structure in forest soils. Appl. Microbiol. Biotechnol. 2018, 102, 4331-4338. [CrossRef]

61. Wu, J.; Liu, Z.; Wang, X.; Sun, Y.; Zhou, L.; Lin, Y.; Fu, S. Effects of understory removal and tree girdling on soil microbial community composition and litter decomposition in two Eucalyptus plantations in South China. Funct. Ecol. 2011, 25, 921-931. [CrossRef]

62. Bani, A.; Pioli, S.; Ventura, M.; Panzacchi, P.; Borruso, L.; Tognetti, R.; Tonon, G.; Brusetti, L. The role of microbial community in the decomposition of leaf litter and deadwood. Appl. Soil Ecol. 2018, 126, 75-84. [CrossRef]

63. Lauber, C.L.; Strickland, M.S.; Bradford, M.A.; Fierer, N. The influence of soil properties on the structure of bacterial and fungal communities across land-use types. Soil Biol. Biochem. 2008, 40, 2407-2415. [CrossRef]

64. Shihan, A.; Hättenschwiler, S.; Milcu, A.; Joly, F.-X.; Santonja, M.; Fromin, N. Changes in soil microbial substrate utilization in response to altered litter diversity and precipitation in a Mediterranean shrubland. Biol. Fertil. Soils 2016, 53, 171-185. [CrossRef]

65. Högberg, M.N.; Högberg, P. Extramatrical ectomycorrhizal mycelium contributes one-third of microbial biomass and produces, together with associated roots, half the dissolved organic carbon in a forest soil. New Phytol. 2002, 154, 791-795. [CrossRef] [PubMed]

66. Tian, J.; McCormack, L.; Wang, J.; Guo, D.; Wang, Q.; Zhang, X.; Yu, G.; Blagodatskaya, E.; Kuzyakov, Y. Linkages between the soil organic matter fractions and the microbial metabolic functional diversity within a broad-leaved Korean pine forest. Eur. J. Soil Biol. 2014, 66, 57-64. [CrossRef]

67. Huang, M.; Chai, L.; Jiang, D.; Zhang, M.; Jia, W.; Huang, Y. Spatial patterns of soil Fungal communities are driven by dissolved organic matter (DOM) quality in semi-arid regions. Microb. Ecol. 2020, 82, 202-214. [CrossRef] [PubMed]

68. Yano, Y.; McDowell, W.; Aber, J. Biodegradable dissolved organic carbon in forest soil solution and effects of chronic nitrogen deposition. Soil Biol. Biochem. 2000, 32, 1743-1751. [CrossRef]

69. Wan, X.; Huang, Z.; He, Z.; Yu, Z.; Wang, M.; Davis, M.R.; Yang, Y. Soil C:N ratio is the major determinant of soil microbial community structure in subtropical coniferous and broadleaf forest plantations. Plant Soil 2014, 387, 103-116. [CrossRef]

70. Liang, X.; Yuan, J.; Yang, E.; Meng, J. Responses of soil organic carbon decomposition and microbial community to the addition of plant residues with different C:N ratio. Eur. J. Soil Biol. 2017, 82, 50-55. [CrossRef]

71. Hackl, E.; Bachmann, G.; Zechmeister-Boltenstern, S. Soil microbial biomass and rhizosphere effects in natural forest stands. PHYTON-HORN 2000, 40, 83-90. 